\title{
Quality of Sleep among Portuguese Anaesthesiologists: A Cross-Sectional Study
}

\section{Qualidade de Sono dos Anestesiologistas Portugueses: Um Estudo Transversal}

\author{
Francisco VALENTE $\otimes^{1}$, Catarina BATISTA¹, Vânia SIMÕES ${ }^{1}$, Inês TOMÉ ${ }^{1}$, Alexandre CARRILHO ${ }^{1}$
} Acta Med Port 2019 Oct;32(10):641-646 - https://doi.org/10.20344/amp.11468

\begin{abstract}
Introduction: Sleeping is essential to maintain proper relationships with others, keep alertness, and execute responsibilities, among many other functions. In the medical profession, there are several studies linking sleep deprivation with a decrease in responsiveness, cognition and attention. With this study we intended to characterize the sleep pattern of Portuguese anaesthesiologists and identify independent factors associated with sleep quality in this population.

Material and Methods: An observational, cross-sectional study of senior and resident anesthesiologists working in Portugal was carried out through an online questionnaire. Individuals working exclusively in intensive care units, emergency departments or with previously diagnosed sleep disorders were excluded. Socio-demographic data, Pittsburgh Sleep Quality Index, Epworth Sleepiness Scale and Perceived Stress Scale were applied. Statistical significance was assessed using the Mann-Whitney test and the chi-square test. A multivariable analysis was performed to examine the association between the Pittsburgh Sleep Quality Index and certain variables. Results: Among 256 respondents, 46.1\% reported "poor" quality of sleep (Pittsburgh Sleep Quality Index $>5$ ). Within these individuals, $77.1 \%$ slept less than 7 hours per night $(p<0.001)$. Excessive daytime sleepiness (Epworth Sleepiness Scale $>10)$ was present in $41.0 \%$ of the sample, and the median Perceived Stress Scale score was 17.0. The independent factors associated with worse quality of sleep were the number of working hours/week (OR 1.03, 95\% $\mathrm{Cl} 1,01$ to 1,06), perceived stress (OR 1.18, 95\% Cl 1.11 to 1.26), taking sleep medication (OR 14.72, 95\% Cl 5.55 to 39.08), and sleep hours/night (OR 0.25, 95\% Cl 0.15 to 0.42 ).

Discussion: This fraction of Portuguese anaesthesiologists presented a poorer quality of sleep, with excessive daytime somnolence, perceived stress and higher sedative use compared to previously studied populations.

Conclusion: Our study characterizes sleep patterns and identifies potential risk factors linked to sleep disturbances in a sample of Portuguese anaesthesiologists. Government and institutional policies can endorse sleep hygiene practices and habits, promoting healthier working environments.
\end{abstract}

Keywords: Anesthesiologists; Anesthesiology; Disorders of Excessive Somnolence; Portugal; Sleep; Sleep Deprivation; Sleep Wake Disorders

\section{RESUMO}

Introdução: O sono é essencial para executar tarefas, manter o estado de alerta, executar tarefas, entre outras funções. Diversos estudos na área médica relacionam a privação de sono com a redução da capacidade de resposta, cognição e nível de atenção. Os objetivos deste estudo foram a caracterização do padrão de sono dos anestesiologistas Portugueses e identificação de fatores de risco independentes para pior qualidade de sono.

Material e Métodos: Efetuámos um estudo observacional e transversal em anestesiologistas e internos de formação específica em Anestesiologia a trabalhar em Portugal. Foram excluídos profissionais que trabalham exclusivamente em unidades de cuidados intensivos, serviços de urgência ou com patologias do sono previamente diagnosticadas. Foram colhidos dados sócio-demográficos e aplicadas as escalas de Pittsburgh Sleep Quality Index (PSQI), Epworth Sleepiness Scale (ESS) e Perceived Stress Scale (PSS). A significância estatística foi analisada recorrendo aos testes de Mann-Whitney e qui-quadrado. A associação entre o Pittsburgh Sleep Quality Index e demais variáveis foi testada através de uma regressão logística.

Resultados: Dos 256 casos admitidos, 46,1\% apresentaram "má" qualidade de sono (Pittsburgh Sleep Quality Index > 5). Nestes, $77,1 \%$ dormiram menos de 7 horas por noite $(p<0,001)$. A sonolência diurna excessiva (Epworth Sleepiness Scale $>10)$ surgiu em $41,0 \%$ da amostra e a mediana da Perceived Stress Scale foi 17,0. Os fatores de risco independentes para "má" qualidade de sono foram: número de horas de trabalho semanais (OR 1,03, IC 95\% 1,01 a 1,06), stress percecionado (OR 1,18, IC 95\% 1,11 a 1,26), toma de medicamentos para dormir (OR 14,72, IC 95\% 5,55 a 39,08) e número de horas dormidas por noite (OR 0,25, IC 95\% 0,15 a 0,42). Discussão: A nossa amostra de anestesiologistas Portugueses apresentou pior qualidade de sono, com sonolência diurna excessiva, stress percecionado e uso de sedativos superiores a outras populações previamente estudadas.

Conclusão: O presente estudo caracteriza o padrão de sono e identifica potenciais factores de risco relacionados com distúrbios do sono, numa amostra de Anestesiologistas Portugueses. Políticas de saúde governamentais e institucionais poderão ser orientadas para a promoção da higiene do sono, levando a ambientes de trabalho mais saudáveis.

Palavras-chave: Anestesia; Anestesiologistas; Distúrbios do Sono por Sonolência Excessiva; Portugal; Privação do Sono; Sono; Transtornos do Sono-Vigília

\section{INTRODUCTION}

Sleeping is one of the human being's most basic physiological needs, and is essential to maintain appropriate relationships with others, keep alertness and execute simple or complex assignments. Sleep regulation depends on biological mechanisms as well as external factors, like working schedules, eating quality, professional and domestic activities or outer noise. Sleep requirements fluctuate during

\footnotetext{
1. Serviço de Anestesiologia. Centro Hospitalar de Lisboa Central. Lisboa. Portugal.

$\triangle$ Autor correspondente: Francisco Valente. f.valente@gmail.com

Recebido: 23 de outubro de 2018 - Aceite: 05 de fevereiro de 2019 | Copyright @ Ordem dos Médicos 2019
} 
lifetime, and it is well accepted that at least seven hours of sleep per night, on a regular basis, are required to promote optimal health, among adults of working age. ${ }^{1}$

Sleep disorders are associated with either a disturbance in the duration, quality or timing of sleep and are detrimental on a personal, professional and institutional level. ${ }^{2}$ Physicians tend to have an erratic work schedule, with several periods of shift work per month, including night shifts. Working atypical shifts is associated with increased risk of obesity, hypertension, cardiovascular diseases, type 2 diabetes mellitus, acute respiratory infections, gastrointestinal tract problems, lower immunity, back pain, anxiety, mood disorders and depression..$^{3-5}$

Sleep disturbances are also associated with stress, and both mutually influence each other. According to the World Health Organization, ${ }^{6}$ work stress is thought to affect individuals' psychological and physical health, as well as the effectiveness of organizations. When affected by work, a person may become increasingly distressed and irritable, feel tired, depressed and anxious or have difficulties in sleeping adequately. Also thinking logically and making decisions could be troublesome.

The authors found a lack of studies that evaluate the quality of sleep of anaesthesiologists in Portugal. In 2014, there were a total of 1121 senior anaesthesiologists working in Anaesthesiology departments of the Portuguese public National Health Service, 291 anaesthesiology residents in training and 200 senior anaesthesiologists working in the private system. $^{7}$

Therefore, the first objective of our study was to characterize the sleep pattern of Portuguese anaesthesiologists. The secondary objective was to identify independent factors related with sleep quality in this population.

\section{MATERIAL AND METHODS}

We carried out an observational, descriptive and cross-sectional study. An anonymous online survey was developed and sent by email to all public and private Anaesthesiology Departments and through the Portuguese Society of Anaesthesiology. The survey was piloted on ten anaesthesiologists, and their suggestions were incorporated prior to dissemination. Senior anaesthesiologists and residents were included if they had workloads of at least 35 hours per week. Those working exclusively in intensive care units or emergency departments, and those with a previously diagnosed sleep disorder were excluded. The study was approved by the Ethics Committee of our Hospital (181/2015) and by the Portuguese Data Protection Authority (CNPD 1476/2015). Two reminders were sent two weeks and one month after the initial email, and the survey was closed after 60 days. Two questionnaires were excluded due to implausible responses.

\section{Questionnaire}

The anonymous questionnaire with implicit consent included 25 items, divided in three categories. The first category, named social-demographic characterization, defined the population by personal data (gender, age, marital status, number of children and of people in the household), and consumption of coffee and cigarettes. The second group of items had to do with employment status (present status, years of work, private activity, type of institution, number of weekly working hours, number of nightshifts and 24 hour shifts per week [within the month before]). In the last category, three questionnaires that were adapted and validated for Portuguese language were included - the Pittsburgh Sleep Quality Index (PSQI), ${ }^{8}$ the Epworth Sleepiness Scale $(E S S)^{9,10}$ and the 10-item Perceived Stress Scale (PSS). ${ }^{11,12}$

The PSQI is an instrument that evaluates the pattern of sleep during the month before the assessment and is comprised of 19 items grouped in seven components. A cut-off separates "good" ( $\leq 5)$ from "poor" (> 5) quality of sleep. Regarding the ESS scale, it is used to assess the likelihood of falling asleep in different situations of daily life. Scores greater than 10 represent moderate excessive daytime sleepiness (from 11 to 15) and greater than 15, severe excessive daytime sleepiness (from 16 to 24). It is well accepted in the international literature the use of two-level ESS - normal versus excessive daytime sleepiness. Lastly, the 10-item PSS is a self-assessment quantity scale used as a sign of excessive stress. Scores around 13 are considered average. Scores of 20 or higher are considered high stress. The authors addressed three final questions regarding the impact of sleep deprivation on patient safety, a self-evaluation on their sleep quality and whether they feel that Anaesthesiology is a stressful speciality.

\section{Statistical analysis}

Google Docs ${ }^{\circledR}$ (http://docs.google.com) was used to deliver the survey and collect data, which was then imported into Microsoft Office Excel $2011^{\circledR}$. Statistical analysis was performed using SPSS 23.0.0.0 software package (SPSS, Chicago, IL, USA).

The Shapiro-Wilk test was used to evaluate the hypothesis of normal distribution. Age and sleep hours per night are reported as mean \pm standard deviation. The adding non-normally distributed numerical variables are reported as median (interquartile range), and they were all evaluated using Mann-Whitney U-test. Categorical variables are presented as absolute numbers and proportions and were evaluated using Pearson chi-square test.

A multivariable analysis was performed (binary logistic regression) to examine the association between PSQI scores and certain variables (categorical and continuous). The selection of variables was performed according to their statistical significance $(p<0.05)$ in the univariate analysis. All statistical tests were two-sided and overall statistic significance was set at $p$ value of 0.05 .

\section{RESULTS}

A total of 256 responses were received, representing $15.9 \%$ of Portuguese senior anaesthesiologists and residents $(12.8 \%$ and $29.9 \%$, respectively). Most of the respondents were women $(75,4 \%)$ and the average age 
Table 1 - Results of the three questionnaires applied to the studied population

\begin{tabular}{lcccccc}
\hline Questionnaires $(\mathbf{n}=\mathbf{2 5 6})$ & & $\mathrm{n}$ & $\%$ & & \\
\hline Pittsburgh Sleep Quality Index & "good" & 138 & $53.9 \%$ & & & \\
& "poor" & 118 & $46.1 \%$ & & Median & IQR \\
\hline & Min. & Max. & Mean & SD & 9.00 & 6.00 \\
Epworth Sleepiness Scale & 0.0 & 20.0 & 9.19 & 4.55 & 17.00 & 9.00 \\
\hline
\end{tabular}

n: number of responders; Min: minimum; Max: maximum; SD: standard deviation; IQR: interquartile range

was $39.5 \pm 11.25$ years. Table 1 shows the results obtained from the three questionnaires used.

The average sleep duration was $6.37 \pm 0.80$ hours (min. 4; max. 9). One hundred and eighteen subjects (46.1\%) reported a PSQI score greater than 5 . Within this group, $77.1 \%$ slept less than 7 hours per night in the month before $(p<0.001)$. From the total sample, $41.0 \%$ presented excessive daytime sleepiness (ESS > 10), with $23.0 \%$ having severe excessive daytime sleepiness (ESS > 15). As for the perceived stress, the median PSS score was 17.0 (9.0). Approximately $32 \%$ of the population had PSS scores equal or greater than 20 . Table 2 summarises the demographic characteristics of the population and their correlation with PSQI. Table 3 discloses the independent factors associated with PSQI greater than 5. Correspondingly, sleeping more hours per night (numerical variable) is a protective factor for quality of sleep, as opposed to an increase in the number of working hours per week or taking sleep medication at least once a week. For each unit

Table 2 - Demographic characteristics of the population and univariate correlation with PSQI

\begin{tabular}{|c|c|c|c|c|c|c|c|c|}
\hline \multirow{2}{*}{ Variable } & & \multicolumn{4}{|c|}{ Quality of Sleep (PSQI) } & \multirow{2}{*}{$\begin{array}{c}\text { Total } \\
(n=256) \\
n(\%)\end{array}$} & \multirow{2}{*}{$\begin{array}{c}\text { Total } \\
\text { (numerical } \\
\text { variables) }\end{array}$} & \multirow[b]{2}{*}{$p$} \\
\hline & & \multirow{2}{*}{\multicolumn{2}{|c|}{$\begin{array}{c}\text { "good" } \\
(\mathrm{n}=138 \mid 53.9 \%) \\
38.70 \pm 11.50\end{array}$}} & \multirow{2}{*}{\multicolumn{2}{|c|}{$\begin{array}{c}\text { "poor" } \\
(\mathrm{n}=118 \mid 46.1 \%) \\
40.48 \pm 10.92\end{array}$}} & & & \\
\hline \multicolumn{2}{|l|}{ Age, in years ${ }^{\circ}$} & & & & & & $39.54 \pm 11.25$ & N.S. \\
\hline Gender & $\begin{array}{l}\text { Female } \\
\text { Male }\end{array}$ & $\begin{array}{l}99 \\
39\end{array}$ & $\begin{array}{l}71.7 \% \\
28.3 \%\end{array}$ & $\begin{array}{l}94 \\
24\end{array}$ & $\begin{array}{l}79.7 \% \\
20.3 \%\end{array}$ & $\begin{array}{r}193(75.4 \%) \\
63(24.6 \%)\end{array}$ & & N.S. \\
\hline Marital status & $\begin{array}{l}\text { Unmarried } \\
\text { Married / Living together }\end{array}$ & $\begin{array}{l}54 \\
84\end{array}$ & $\begin{array}{l}39.1 \% \\
60.9 \%\end{array}$ & $\begin{array}{l}42 \\
76\end{array}$ & $\begin{array}{l}35.6 \% \\
64.4 \%\end{array}$ & $\begin{array}{r}96(37.5 \%) \\
160(62.5 \%)\end{array}$ & & N.S. \\
\hline Number of children & $\begin{array}{l}0 \\
1 \text { or more }\end{array}$ & $\begin{array}{l}72 \\
66\end{array}$ & $\begin{array}{l}52.2 \% \\
47.8 \%\end{array}$ & $\begin{array}{l}57 \\
61\end{array}$ & $\begin{array}{l}48.3 \% \\
51.7 \%\end{array}$ & $\begin{array}{l}129(50.4 \%) \\
127(49.6 \%)\end{array}$ & & N.S. \\
\hline Smoking habits & $\begin{array}{l}\text { No } \\
\text { Yes }\end{array}$ & $\begin{array}{r}118 \\
20\end{array}$ & $\begin{array}{l}85.5 \% \\
14.5 \%\end{array}$ & $\begin{array}{r}102 \\
16\end{array}$ & $\begin{array}{l}86.4 \% \\
13.6 \%\end{array}$ & $\begin{array}{r}220(85.9 \%) \\
36(14.1 \%)\end{array}$ & & N.S. \\
\hline Coffee intake & $\begin{array}{l}\text { No } \\
\text { Yes }\end{array}$ & $\begin{array}{r}11 \\
127\end{array}$ & $\begin{array}{r}8.0 \% \\
92.0 \%\end{array}$ & $\begin{array}{r}11 \\
107\end{array}$ & $\begin{array}{r}9.3 \% \\
90.7 \%\end{array}$ & $\begin{array}{r}22(8.6 \%) \\
234(91.4 \%)\end{array}$ & & N.S. \\
\hline Weekly physical activity & $\begin{array}{l}\text { Zero } \\
\text { Once or more }\end{array}$ & $\begin{array}{l}40 \\
98\end{array}$ & $\begin{array}{l}29.0 \% \\
71.0 \%\end{array}$ & $\begin{array}{l}41 \\
77\end{array}$ & $\begin{array}{l}34.7 \% \\
65.3 \%\end{array}$ & $\begin{array}{r}81(31.6 \%) \\
175(68.4 \%)\end{array}$ & & N.S. \\
\hline Employment status & $\begin{array}{l}\text { Resident } \\
\text { Senior Anaesthesiologist }\end{array}$ & $\begin{array}{l}54 \\
84\end{array}$ & $\begin{array}{l}39.1 \% \\
60.9 \%\end{array}$ & $\begin{array}{l}33 \\
85\end{array}$ & $\begin{array}{l}28.0 \% \\
72.0 \%\end{array}$ & $\begin{array}{r}87(34.0 \%) \\
169(66.0 \%)\end{array}$ & & N.S. \\
\hline $\begin{array}{l}\text { Number of years as } \\
\text { physician }\end{array}$ & $\begin{array}{l}1 \text { to } 15 \\
16 \text { or more }\end{array}$ & $\begin{array}{l}94 \\
44\end{array}$ & $\begin{array}{l}68.1 \% \\
31.9 \%\end{array}$ & $\begin{array}{l}70 \\
48\end{array}$ & $\begin{array}{l}59.3 \% \\
40.7 \%\end{array}$ & $\begin{array}{r}164(64.1 \%) \\
92(35.9 \%)\end{array}$ & & N.S. \\
\hline Private sector work & $\begin{array}{l}\text { No } \\
\text { Yes }\end{array}$ & $\begin{array}{l}77 \\
61\end{array}$ & $\begin{array}{l}55.8 \% \\
44.2 \%\end{array}$ & $\begin{array}{l}67 \\
51\end{array}$ & $\begin{array}{l}56.8 \% \\
43.2 \%\end{array}$ & $\begin{array}{l}144(56.3 \%) \\
112(43.7 \%)\end{array}$ & & N.S. \\
\hline \multicolumn{2}{|l|}{ Weekly work hours * } & \multicolumn{2}{|c|}{$51.5(13.5)$} & \multicolumn{2}{|r|}{$60(15.5)$} & & $53.0(12.0)$ & $<0.05$ \\
\hline \multicolumn{2}{|l|}{ Monthly night shifts * } & \multicolumn{2}{|c|}{$4(5.0)$} & \multicolumn{2}{|c|}{$4(4.0)$} & & $4.0(4.0)$ & N.S. \\
\hline Monthly 24 hours shifts & $\begin{array}{l}4 \text { or less } \\
5 \text { or more }\end{array}$ & $\begin{array}{l}94 \\
44\end{array}$ & $\begin{array}{l}68.1 \% \\
31.9 \%\end{array}$ & $\begin{array}{l}75 \\
43\end{array}$ & $\begin{array}{l}63.6 \% \\
36.4 \%\end{array}$ & $\begin{array}{r}169(66.0 \%) \\
87(34.0 \%)\end{array}$ & & N.S. \\
\hline Sleep hours per night ${ }^{\circ}$ & & 6.6 & $5 \pm 0.70$ & & $04 \pm 0.80$ & & $6.37 \pm 0.80$ & $<0.001$ \\
\hline $\begin{array}{l}\text { Sleep hours per night } \\
\text { (dichotomous) }\end{array}$ & $\begin{array}{l}<7 \mathrm{~h} \\
\geq 7 \mathrm{~h}\end{array}$ & $\begin{array}{l}66 \\
72\end{array}$ & $\begin{array}{l}47.8 \% \\
52.2 \%\end{array}$ & $\begin{array}{l}91 \\
27\end{array}$ & $\begin{array}{l}77.1 \% \\
22,9 \%\end{array}$ & $\begin{array}{r}157(61.3 \%) \\
99(38.7 \%)\end{array}$ & & $<0.001$ \\
\hline $\begin{array}{l}\text { Intake of sleep } \\
\text { medication at least once } \\
\text { a week (prescribed or } \\
\text { not) }\end{array}$ & $\begin{array}{l}\text { Never } \\
\text { At least once a week }\end{array}$ & $\begin{array}{r}127 \\
11\end{array}$ & $\begin{array}{r}92.0 \% \\
8.0 \%\end{array}$ & $\begin{array}{l}74 \\
44\end{array}$ & $\begin{array}{l}62.7 \% \\
37.3 \%\end{array}$ & $\begin{array}{r}201(78.5 \%) \\
55(21.5 \%)\end{array}$ & & $<0.001$ \\
\hline Epworth Sleepiness Scale & & & $8(7.0)$ & & $10.5(7.0)$ & & $9.0(6.0)$ & $<0.01$ \\
\hline Perceived Stress * & & & $14(7.3)$ & & $20(7.0)$ & & $17.00(9.0)$ & $<0.001$ \\
\hline
\end{tabular}

Statistic tests applied: Mann-Whitney U-test for numerical and Pearson Chi-square test for categorical variables.

:: numerical variable, expressed as mean + standard deviation; *: Numerical variable, expressed as median + interquartile range; N.S.: not significant. 
Table 3 - Multivariable statistic analysis of factors associated with PSQI > 5 ("poor" quality of sleep)

\begin{tabular}{lcc}
\hline & OR (95\% Cl) & $p$ \\
\hline Sleep hours per night & $0.25(0.15$ to 0.42$)$ & $p<0.001$ \\
Weekly work hours & $1.03(1.01$ to 1,06$)$ & $p<0.05$ \\
Perceived stress & $1.18(1.11$ to 1.26$)$ & $p<0.001$ \\
$\begin{array}{l}\text { Intake of sleep medication at least once a week } \\
\text { (prescribed or not) }\end{array}$ & $14.72(5.55$ to 39.08$)$ & $p<0.001$ \\
Epworth Sleepiness Scale & - & N.S. \\
\hline
\end{tabular}

Binary Logistic Regression applied. OR: odds ratio; Cl: confidence interval; N.S.: not significant.

increase in the Perceived Stress Scale, the odds of "poor" quality of sleep increase by 1.18 times.

Fifty-five individuals $(20.7 \%)$ revealed that they took sleep medication at least once a week, with 48 taking benzodiazepines exclusively. From the total number of respondents, 38.3\% replied positively to the question "Have you ever felt that your number of hours of sleep could compromise patient safety?", and $45.3 \%$ replied to the question "Do you consider the specialty of Anaesthesiology stressful?" with frequently or often.

\section{DISCUSSION}

The present study documents "poor" quality of sleep in approximately $46 \%$ of participating Portuguese anaesthesiologists, which is higher than the incidence in French anaesthesiologists, ${ }^{13}$ but lower compared to what is described in other specialties. ${ }^{14}$ Excessive daytime sleepiness (defined by ESS > 10) was a concerning discovery in our sample, significantly higher than in healthcare professionals and in the rural general population, as previously studied. ${ }^{15,16}$ Also, the incidence of severe excessive daytime sleepiness was higher than in the French study. ${ }^{13}$ Regarding the perceived stress, we found PSS scores again significantly higher compared to those in a recent study in the Danish population (median of 11). ${ }^{17}$ Our findings reveal that sleeping less than seven hours per night has a correlation with PSQI greater than 5 . Furthermore, the number of weekly work hours, taking sleep medication and perceived stress are independent risk factors for "poor" quality of sleep, in contrast to sleeping more hours per night, which is protective. These findings are in line with previous studies performed in anaesthesiologists. ${ }^{13,18,19}$ Apart from a correlation, we did not find an independent association between PSQI and ESS.

It is well known that Anaesthesiology is a cornerstone structure in the day-to-day activities of a hospital. Effective patient care performed by an anaesthesiologist demands assimilation of multiple variables concerning the patient's condition and actual status, high levels of vigilance and anticipation of eventual complications. ${ }^{19}$ Our study reveals that the median of weekly working hours was 53 hours. Allied to this fact, the unpredictability of work, mostly in the urgent/emergent setting, and pressures of productivity could be some of the explanations for the sleep disturbances and perceived stress observed in this study. ${ }^{19-22}$ Some international institutions are creating regulations and laws on reducing physician work hours in light of this matter. ${ }^{23}$
The erratic work schedule of physicians, with weekby-week variations between morning, afternoon or night shifts, make them vulnerable to Shift Work Sleep Disorder - a condition that results from atypical shifts (i.e. other than the typical 9 am to $5 \mathrm{pm}$ schedule). ${ }^{5}$ Individuals suffering from this condition have an increased risk of cardiovascular disease, gastrointestinal disturbances, psychological disturbances related with mental tiredness, exhaustion, altered mood and chronic fatigue, and even cancer, probably due to melatonin, cortisol or prolactin suppression. $5,24,25$ The findings of our study can encourage occupational health services to develop strategies against the circadian misalignment in work shifts.

Under-performance of physicians related with sleep deprivation has been subject to many studies. ${ }^{15,26,27}$ As a matter of fact, psychomotor performance, cognition, attention, memory, motivation and capacity to assimilate new learning are impaired with this deficit, with potential catastrophic outcomes for patient care. What is also clear is the relationship between hours of sleep and occupational fatigue ${ }^{3,4}$ In order to address this subject, the Association of Anaesthetists of Great Britain \& Ireland reviewed their recommendations on fatigue in $2014 .{ }^{28}$ The authors of this study incite every policy maker, hospital administrator and healthcare professional to read that document in order to prevent or minimize disease in anaesthesiologists, reduce tiredness, and, ultimately, improve patient safety.

Interestingly, despite our research not being suited to support these findings, emotional exhaustion had a lower prevalence in older Portuguese anaesthesiologists in the past. ${ }^{29}$ This was attributed to the development of coping mechanisms throughout the years. In fact, medical professionals use many sorts of coping strategies aimed at attenuating the effect of fatigue in avoidable medical errors and in daily gestures. Those can vary from actively seeking support or taking power naps during shifts to not coming to work when too fatigued or having burnout symptoms when coping is wrongly perceived. ${ }^{3,30}$ Ultimately, this can lead to excessive stress and severe depression, with their intimate relationship with suicidal ideation and drug-abuse. ${ }^{26,31,32}$

Likewise, an alarming discovery in our work was the consumption of sleep medication at least once per week in $20.7 \%$ of respondents. This is higher than the prevalence in the general population, for instance in Canada $(5.5 \%),{ }^{33}$ Norway $(7.9 \%)^{34}$ or Israel $(8.7 \%) .^{35}$ When asked to specify, $87.3 \%$ of our population answered benzodiazepines as 
the medicine of choice, contrasting with $67.1 \%$ in Norway. ${ }^{34}$ According to the Portuguese Directorate- General of Health, ${ }^{36}$ Portugal is the EU country with the highest consumption of this pharmacological class per inhabitant. Further research is warranted in this area of discussion, with measurement of possible consequences of this substance abuse in association with clinical and psychological interventions.

There are several limitations to our study. First and foremost, the number of respondents represented only $15.9 \%$ of the studied population, and consequently our results cannot be generalised and should be analysed only as a reflection of the reality of Portuguese anaesthesiologists. Secondly, the authors assume a recall bias - the questions in our survey were retrospective in nature (previous month) and therefore the answers may have been be blurred by imprecise recollection. Moreover, only interested individuals who had experienced sleep or stress disturbances may have been more likely to express interest in this survey. On the other hand, social desirability bias may also have influenced some responses, for instance regarding sedative use. In addition, this was a subjective self-reported questionnaire, so facts regarding previously diagnosed sleep disorders, sleep quality or daytime somnolence should be interpreted with caution as an in-person clinical interview, polysomnography or actigraphy are the generally accepted instruments in the identification of most sleep disorders. We assume the possible existence of confounding factors not taken in account with this study, for instance blue-light exposure before sleep, children's age, room temperature or resting periods during night shifts, for instance. Finally, even though this survey was subjected to a pilot test, some questions may have been poorly perceived by responders due to writing issues.

\section{CONCLUSION}

This study characterizes sleep patterns and identifies potential risk factors linked to sleep disturbances in a sample of Portuguese anaesthesiologists. Indeed, quality of sleep was poorer, with excessive daytime somnolence, perceived stress and sedative use higher than previous series in other populations. Nearly half of respondents consider Anaesthesiology as a stressful specialty. Both government and institutional policies should promote a healthier working environment, reduce stress and endorse sleep hygiene practices and habits.

\section{ACKNOWLEDGEMENTS}

We would like to show our gratitude to Isabel Fragata (Head of Department of Anaesthesiology) who provided insight and expertise that greatly assisted this research. We acknowledge Daniel Virella and Marta Alves from the Investigation Centre of Centro Hospitalar Lisboa Central, and Ana Papoila from NOVA Medical School - NOVA University of Lisbon for the assistance with study design and follow up. The authors would also like to thank all the questionnaire responders.

\section{PROTECTION OF HUMANS AND ANIMALS}

The authors declare that the procedures were followed according to the regulations established by the Clinical Research and Ethics Committee and to the Helsinki Declaration of the World Medical Association.

\section{DATA CONFIDENTIALITY}

The authors declare having followed the protocols in use at their working center regarding patients' data publication.

\section{CONFLICTS OF INTEREST}

The authors have no conflicts of interest to declare.

\section{FUNDING SOURCES}

This research received no specific grant from any funding agency in the public, commercial, or not-for-profit sectors.

\section{REFERENCES}

1. Watson NF, Badr MS, Belenky G, Bliwise DL, Buxton OM, Buysse D, et al. Recommended amount of sleep for a healthy adult: a joint consensus statement of the American Academy of Sleep Medicine and Sleep Research Society. J Clin Sleep Med. 2015;11:591-2.

2. American Academy of Sleep Medicine. The international classification of sleep disorders: diagnostic and coding manual. $2^{\text {nd }}$ ed. Westchester: AASM; 2005.

3. Stuetzle KV, Pavlin BI, Smith NA, Weston KM. Survey of occupational fatigue in anaesthetists in Australia and New Zealand. Anaesth Intensive Care. 2018;46:414-23

4. Ferguson SA, Paech GM, Dorrian J, Roach GD, Jay SM. Performance on a simple response time task: Is sleep or work more important for miners? Appl Ergon. 2011;42:210-3.

5. Jehan S, Zizi F, Pandi-Perumal SR, Myers AK, Auguste E, Jean-Louis G, et al. Shift work and sleep: medical implications and management. Sleep Med Disord. 2017;1:pii: 00008.

6. Institute of Work, Health of Work, Health \& Organizations, Leka S, Griffiths A, Cox T. Work organisation \& stress. WHO Library Cataloguingin-Publication Data. Geneve: WHO; 2003.

7. Lemos P, Lima JF, Viana J, Assunção JP, Veiga J, Manuel, et al. Censos anestesiologia - 2014. Relatório final. Rev Soc Port Anestesiol. 2015;24:41-52

8. Buysse DJ, Reynolds CF, Monk TH, Berman SR, Kupfer DJ. The

Pittsburgh sleep quality index: a new instrument for psychiatric practice and research. Psychiatr Res. 1989;28:193-213.

9. Johns MW. A new method for measuring daytime sleepiness: the Epworth sleepiness scale. Sleep. 1991;14:540-5.

10. Centro de Estudo e Investigação em Saúde da Universidade de Coimbra, Laboratório de Estudos de Patologia de Sono. Sleep Disorders Unit EpworthHospital, Melbourne, Victoria,AustraliabyMarrayW. Johns, Ph.D. Centro Hospitalar de Coimbra. [accessed 2015 Jun 1]. Available from: http://www.sleepontario.com/docs/scales/ESS/ESS_Portugese.pdf.

11. Cohen S, Kamarck T, Mermelstein R. A global measure of perceived stress. J Health Soc Behav. 1983;24:385-96.

12. Trigo M, Canudo N, Branco F, Silva D. Estudo das propriedades psicométricas da Perceived Stress Scale (PSS) na população portuguesa. Psychologica. 2010;53:353-78.

13. Richter E, Blasco V, Antonini F, Rey M, Reydellet L, Harti K, et al. Sleep disorders among French anaesthesiologists and intensivists working in public hospitals. Eur J Anaesthesiol. 2015;32:132-7.

14. Tür FC, Toker I, Tür B, Hacar $S$, Türe $B$. Assessment of the Pittsburgh Sleep Quality Index among physician's speciality who work night shifts. Emerg Med Open J. 2015;1:5-11.

15. Espuga M, Maria AR, Ayora A, Alonso M, Sampol G, et al. Sleep habits and excessive daytime sleepiness in a population of Spanish health care employees. J Sleep Disord Manag. 2016;2:011. 
16. Pahwa P, Karunanayake CP, Hagel L, Gjevre JA, Rennie D, Lawson J, et al. Prevalence of high Epworth Sleepiness Scale Scores in a rural population. Can Respir J. 2012;19:e10-4.

17. Prior A, Vestergaard M, Larsen KK, Fenger-Gron M. Association between perceived stress, multimorbidity and primary care health services: a Danish population-based cohort study. BMJ Open. 2018;8:e018323

18. Sinha A, Singh A, Tewari A. The fatigued anesthesiologist: a threat to patient safety? J Anaesthesiol Clin Pharmacol. 2013;29:151-9.

19. Sanches I, Teixeira F, Santos JM, Ferreira AJ. Effects of acute sleep deprivation resulting from night shift work on young doctors. Acta Med Port. 2015;28:457-62.

20. McClelland L, Holland J, Lomas JP, Redfern N, Plunkett E. A national survey of the effects of fatigue on trainees in anaesthesia in the UK. Anaesthesia. 2017;72:1069-77.

21. Seeley HF. The practice of anaesthesia-a stressor for the middle-aged? Anaesthesia. 1996;51:571-4

22. Gaba DM, Howard SK, Jump B. Production pressure in the work environment. California anesthesiologists' attitudes and experiences. Anesthesiology. 1994;81:488-500.

23. Blum A, Shea S, Czeisler C, Landrigan C, Leape L. Implementing the 2009 Institute of Medicine recommendations on resident physician work hours, supervision, and safety. Nat Sci Sleep. 2011;3:47-85.

24. Matheson A, O'Brien L, Reid JA. The impact of shiftwork on health: a literature review. J Clin Nurs. 2014;23:3309-20.

25. Smith MR, Eastman Cl. Shift work: health, performance and safety problems, traditional countermeasures, and innovative management strategies to reduce circadian misalignment. Nat Sci Sleep. 2012;4:111-32.

26. Howard SK. Sleep deprivation and physician performance: Why should I care? Proc (Bayl Univ Med Cent). 2005;18:108-12.
27. Amirian I. The impact of sleep deprivation on surgeons' performance during night shifts. Dan Med J. 2014;61:B4912.

28. Association of Anaesthetists of Great Britain \& Ireland. Fatigue and anaesthetists. [accessed 2018 Sep 1]. Available from: https://www. aagbi.org/sites/default/files/Fatigue\%20Guideline\%20web.pdf.

29. Morais A, Maia P, Azevedo A, Amaral C, Tavares J. Stress and burnout among Portuguese anaesthesiologists. Eur J Anaesthesiol. 2006;23:433-9.

30. Saadat H, Bissonnette B, Tumin D, Raman V, Rice J, Barry N, et al. Effects of partial sleep deprivation on reaction time in anesthesiologists. Paediatr Anaesth. 2017;27:358-62.

31. Booth JV, Grossman D, Moore J, Lineberger C, Reynolds JD, Reves JG et al. Substance abuse among physicians: a survey of academic anesthesiology programs. Anesth Analg. 2002;95:1024-30.

32. Bryson EO, Levine A. One approach to the return to residency for anesthesia residents recovering from opioid addiction. J Clin Anesth. 2008;20:397-400.

33. Vozoris NT, Leung RS. Sedative medication use: prevalence, risk factors, and associations with body mass index using population-level data. Sleep. 2011;34:869-74

34. Omvik S, Pallesen S, Bjorvatn B, Sivertsen B, Havik OE, Nordhus IH. Patient characteristics and predictors of sleep medication use. Int Clin Psychopharmacol. 2010;25:91-100.

35. Marom O, Rennert G, Stein N, Landsman K, Pillar G. Characteristics and trends in hypnotics consumption in the largest health care system in Israel. Sleep Disord. 2016;2016:8032528.

36. Health General Directorate Portuguese. Depressão e outras perturbações mentais comuns. [accessed 2018 Sep 04]. Available from: https://www.dgs.pt/ficheiros-de-upload-2013/dms2017-depressao-eoutras-perturbacoes-mentais-comuns-pdf.aspx. 